\title{
John Bates Clark on Trusts: \\ New Light from the Columbia Archives
}

\author{
Luca Fiorito and John F. Henry*
}

\begin{abstract}
The paper sheds new light on John Bates Clark's mature position on the “trust” issue. Access to previously unpublished 1911 testimony before the Interstate Commerce Committee of the U.S. Senate, it is shown that, although Clark relied generally on competitive forces to keep monopoly power in check, following the Standard Oil and American Tobacco cases of that year, he lost considerable faith in the power of his concept of "potential competition," or latent competition that may or may not be realized. What he advocates here is government promotion of actual competition, largely through the dissolution of the "perilous" trusts and the development of a common pricing policy where all producers face the same price regimes in both the output and input markets. What is desired as an outcome is the promotion of what Clark terms "tolerant competition.” Tolerant competition is not the perfect competition of the neoclassical model, nor the rough-andready competition of the pre-1870 era. Rather, it is a live-and-let-live form of competition where big firms and small firms face the same pricing conditions and only efficiency determines the profit outcome.
\end{abstract}

Public concern over the so called "trust problem" in the United States between the end of the nineteenth century and 1914, the year of the passage of the Clayton Act, was reflected in the considerable contemporary literature on the subject. Not surprisingly, professional economists actively participated to this debate. Their thinking directly and indirectly influenced the legislation 
of 1914 in a way that cannot be said of the Sherman Act of 1890 (Mayhew, 1998) ${ }^{1}$. A survey of the most important of these professional writings shows that, among the several voices which animated the discussion, John Bates Clark's was perhaps the most influential. In this connection, Joseph Dorfman argues that John Bates Clark’s second edition of his Control of Trusts (1912), co-authored with his son John Maurice, "played a formative historical role in policy making, for it provided the most systematic exposition of the view on trusts, that was embodied in 1914, at President Woodrow Wilson's urging, in the Clayton Act and the Federal Trade Commission Act." "From this standpoint," continues Dorfman quite emphatically, “The Control of Trusts caught the dominant reform interest and in turn become a contributing force in shaping the trend of the socio-economic development of the nation.” (Dorfman 1971, 17). Apart from the 1912 monograph, John Bates Clark devoted considerable attention to the problems of trusts and industrial combinations during much of his career, both in his professional writings and in his frequent contributions to newspapers and popular reviews.

Dorfman in his introduction to the reprint of the second edition of The Control of Trusts provides lengthy evidence of correspondence in 1914 between Clark and Senator Francis Newlands, a prime mover in the development of the both the Clayton and Federal Trade Commission Acts. This is interesting because it shows that Clark and Newlands got in touch after 1911 and that Senator Newlands relied on Clark's opinion about "three tentative bills (one of which would become the Clayton Act) enclosed with your letter.”

The aim of this note is to introduce unpublished testimony given by John Bates Clark before the Interstate Commerce Committee of the Senate in $1911^{2}$

\footnotetext{
${ }^{1}$ As early as in 1915, commenting on the passage of the Clayton Act, Allyn Young observed: "Furthermore, it is significant that in much of the more serious discussion, both the analysis of the problem and the proposals of the specific remedies involved the recognition of certain principles that for some years had been very generally accepted among economists. Specific instances of the direct influence of economic writing and teaching have not been lacking, and it is fair to infer that through a process of gradual diffusion the indirect influence has been considerable.” (Young 1915, 204).

${ }^{2}$ The transcript of the testimony is found in the Rare Book and Manuscript Room, Columbia University.
} 


\section{What Happened in 1911?}

The 1911 oil and tobacco cases were the most important pre-1914 cases concerning the legality of combinations brought about by either stock or asset acquisition, and substantially contributed to the demand for for the passage of the Clayton Act. The American Tobacco Company was primarily the result of a series of asset acquisitions, although it also involved the acquisition of competitors' stock. The Standard Oil Company of New Jersey was primarily a combination brought about as a holding company by the acquisition of stock. The goverment won both cases, thus demonstrating that under the Sherman Act a combination of manufacturing concerns could be dissolved, whether organized under the corporate form as a holding company or as a single corporation. The most important aspect of these decisions was that the defendants were found to have violated the Sherman Act not because of a restraint of trade, but because of an unreasonable restraint of trade. On the basis of the principle of the "rule of reason," the government could establish that restraint of trade had indeed occurred. The defendant could then argue that such restraint was "reasonable." Clearly, in these cases the defendants were unsuccessful in their bid to demonstrate that their activities were of a reasonable sort. (See Liebhafsky, 1971, 265-9 for an elaboration of this principle with regard to the above cases.)

The 1911 Supreme Court ruling against the American Tobacco Company and the Standard Oil Company clarified state economic policy concerning actions of a holding company. Both trusts used the pyramided holding company to control several subsidiary corporations and gain market control. The court held that the pyramided structure of the American Tobacco constituted "unreasonable restraint of trade.” These decisions showed that “...the state was becoming more concerned about the use of the pyramided corporate structure to gain market control than about market control per se. It was the ability of corporations to control markets by controlling the assets subsidiaries they did not fully own that the state managers found problematic” (Prechel, 2000, 64). 
The relevance of the 1911 cases did not pass unnoticed by prominent economists in the field of trusts. In 1912, The Journal of Political Economy devoted two issues, 4 and 5, and much of number 6 to the so-called trust problem. In that same year, the American Academy of Political and Social Science devoted its Annal to the topic of "Industrial Competition and Combination." Included in this volume was an essay by Clark on "The Possibility of Competition in Commerce and Industry.” Two representative statements follow. It should be noted that Henry Seager was a fellow Columbia University economist and personal friend of Clark, while Jeremiah Jenks was perhaps the most noted industrial organization economist of his day.

The recent decisions [Standard Oil and American Tobacco cases] will exert an important influence on future developments in three different directions. (1) They constitute precedents for future decisions. (2) They should contribute toward that clearer formulation of public policy with reference to combinations and corporations engaged in interstate commerce that is one of the most urgent duties now resting on the Congress of the United States. (3) They must affect the forms of organization which the business of the country will assume in future years.

It is one of the disappointing aspects of the decisions that they fail to answer clearly the question which just now most vitally concerns the business community, namely, how far does the statute as interpreted by the court go in its condemnation of great industrial combinations? To present the problem concretely: is the United States Steel Corporation a combination in restraint of trade in the statutory sense or not? I have read with care the reasons given in the decisions for condemning the Standard Oil Company and the American Tobacco Company, and I must confess my inability to give a confident answer to this question....

The influence which the decisions will have on the forms of business organization to be adopted in the future depends very largely on the promptness and statesmanship which 
Congress may display in working out a regulative policy for industrial combinations.... Under a wise regulative policy it is probable that many different forms of organization would flourish side by side. At the same time protection from unfair and oppressive methods of competition would be a great encouragement to the small producer and would enable him to regain some of the ground he has lost in the unequal competition he has frequently been compelled to carry on with the unregulated trust...(Seager, 1911, pp. 611-14).

The essential purpose of this paper, however, is not to suggest remedies, but rather to call attention to what seems to the fact, that the Supreme Court in these two decisions has failed to take sufficiently into account the economic benefits that come from the saving of industrial energy and the promotion of industrial efficiency by industrial combination....It is submitted that a method of procedure should be found, either by the legislative departments of by the courts, that, while protecting the public interest from direct harm, shall serve the public interest by keeping the benefits of combinations (Jenks, 1912, 357).

\section{A Consequence of the 1911 Cases:}

Reactions to the 1911 court decisions were not limited to the economics community; these cases had important consequences in the larger political arena as well. The Interstate Commerce Committee of the Senate, of which Democrat Senator Albert Cummins was Chairman, called for an inquiry into the whole of antitrust law, an inquiry whose hearings lasted from November of 1911 into the following spring. In his insightful and well documented historical reconstruction of the events prompted by this inquiry, William Letwin tells us that lengthy testimony was taken from over one hundred experts in the field, including leading businessmen such as the steel tycoons Andrew Carnegie and James A. Farrell; lawyers who had been serving as consultants in previous antitrust cases such as Victor Morawets and Louis D. Brandeis; labor leaders and public affair 
specialists such as Samuel Gompers and Lyman Abbott; and eminent economists such as J. Lawrence Laughlin and John Bates Clark.

"From these men the Senate Committee had taken testimony on all the many particular proposals for amending the antitrust law. It had heard suggestions ranging from the total abandonment of the Sherman Act to the strenghtening of the act by attaching to it long lists of prohibited practices and long glossaries defining for the courts its essential terms” (Letwin 1965, 268).

\section{The Place of J.B. Clark}

J. B. Clark was arguably the most prominent U.S. economist by the turn of the twentieth century. Best known for his 1899 The Distribution of Wealth, Clark was also one of the more important authorities on issues associated with "the trusts." Writing in some of the popular outlets of the day as well as in the professional journals, Clark also wrote for The Independent, a religious monthly associated with the Social Gospel movement. As well, he contributed two books, The Control of Trusts (1901 that was revised in 1912 with his son, John Maurice Clark as co-author), and The Problem of Monopoly (1904) that was based on a Cooper Union, New York lecture series. By the time of the 1911 testimony, Clark was a well known industrial organization economist and was well placed to add to the information being compiled by the Senate Committee.

Clark was not a "trust-buster" in the tradition of Theodore Roosevelt and the Progressive Movement that was so prominent in the first two decades of the century. Rather, he took the position that trusts (or oligopolistic organizations in general) were a "natural” phenomenon and were simply the outcome of technological change coupled to increasing returns to scale that could be captured by large industrial organizations (Clark, 1900). The contest was not between big and small business but "honest” and “dishonest” capital. Honest capital secures gains through advancing technology, thus increasing productivity and reducing costs—a benefit to consumers—while 
dishonest capital is garnered through speculation, financial manipulation, and assorted other nefarious activities. Proper policy, then, is to assure that the efficiency gains based on scale are preserved, while pricing power based solely on size is reduced or eliminated. (For all this and what follows, see Henry, 1995, 117-26.)

In the final analysis, Clark generally saw government policy as ineffectual, mainly because of bureaucratic problems, but also because it would be difficult, if not impossible, for officials to discover the true, competitive price based on costs of production and which would be necessary to establish the "correct” price large firms should charge. Moreover, if government were to intervene in the pricing decision, this would no doubt stifle technological change as it would interfere with firms' search for profit. His fundamental solution to the problem of monopoly was "potential competition,” a concept developed as early as 1890 in his “The 'Trust': A New Agent for Doing an Old Work.” Essentially, potential competition is that which would develop if monopolies actually used their economic power to raise prices much above the competitive level. Were this to happen, new competitors would appear to take advantage of the higher profits associated with monopoly pricing and this would force price down to the near-competitive level. In other words, if we do not observe entry into a particular industrial field, existing large corporations are not unduly exercising pricing power.

A quarter of a century ago, when the power of the trusts was beginning to show itself, and the natural limits on the exercise of that power had not appeared, the public had a period of positive alarm. It knew then that the trusts were greedy, but did not know that it was fatal to themselves to be too greedy. The monopolies quickly found this out to their cost... and everyone now knows that "potential competition"...the competition of the mill that is not yet built but will be built if the trust becomes too extortionate- -holds these commercial monsters in check. 
If the trust raise prices too much, new mills are actually built and prices go down; therefore it does not put the prices high enough to call the new mills into being. It is deterred from much extortion which...it would otherwise practice by the competitors who do not now exist (Clark, 1904, 955-6).

While Clark relied generally on competitive forces to keep monopoly power in check, he was not a strict laissez faire economist (and certainly not in favour of nationalization or socialism). ${ }^{3}$ He did see limited scope for government intervention, in particular in those cases where monopolies sold below cost to drive out a rival, where monopoly firms producing various varieties and qualities of a good would charge a lower price for a particular variety sold by the smaller firm, and where “factors agreements,” where firms forced merchants to refuse to purchase a rival’s product, were in effect. The one area where Clark did call for fairly strenuous government regulation was railroads. As railroads serve all industries and no close substitutes for their services exist, government should exercise its regulatory hand in administering prices, though in a rather interesting fashion. Pools should be facilitated in which the various companies would agree upon a common price, divide markets among themselves, and eliminate competition. The cartelized price would be higher than that of a competitive industry, to be sure, but it would be public knowledge. Secret price agreements, the bane of consumers of railroad services, would be eliminated and government would then have a much simpler job in regulating that price to a closer proximity of the competitive standard.

In his 1911 testimony, one can observe all the above arguments represented, but there is one subtle difference from his previously articulated positions. In the then-current period, the force of potential competition has lessened—“dishonest” capital has grown stronger. What is necessary is

\footnotetext{
${ }^{3}$ In 1928, Clark was invited to participate in New York Governor Alfred E. Smith’s campaign for the presidency. In a letter sent by Franklin D. Roosevelt on behalf of Smith, the appeal to Clark is made largely on the basis of Smith's humanitarian impulses (equated to those of Woodrow Wilson) against the "crass materialism" of Herbert Hoover and his associates. John Maurice Clark, in a letter to Dorfman, notes that his father, while clearly not a socialist, was a believer in a "new deal, welfare capitalism” (J. M. Clark to Joseph Dorfman, 1958).
} 
government promotion of actual competition, largely through dissolution of the "perilous" trusts (to be distinguished from those labelled "harmless") and the development of a common pricing policy where all producers face the same price regimens in both the output and input markets. What is necessary is the promotion of what Clark terms "tolerant competition.” Tolerant competition is not the perfect competition of the neoclassical model, nor the rough-and-ready competition of the pre1870 era. Rather, it's a live-and-let-live form of competition where big firms and small firms face the same pricing conditions and only efficiency determines the profit outcome. While the honest trust may well win this contest, such an outcome is not assured. Both large and small producer would face the same external constraints and both (or either) would succeed based upon their ability to advantage themselves through gains in efficiency.

\section{A Note on Clark and the Clayton and Federal Trade Commission Acts}

In the early part of the century, there was much concern in various quarters regarding the uncertainties and vagaries embodied in the Sherman (antitrust) Act of 1890. In particular, large business concerns desired much firmer guidelines as to what constituted restraints on trade and on the determination of what sorts of activities were legal. Various bills, sponsored by business organizations and designed to promote greater federal regulation of the economy in business interests were brought before Congress, but to no avail. On January 20, 1914, President Wilson, speaking before both houses of government, articulated the issue very clearly:

The business of the country awaits also, has long awaited and has suffered because it could not obtain, further and more explicit legislative definition of the policy and meaning of the existing anti-trust law. Nothing hampers business like uncertainty.... And the businessmen of the country desire something more than that the menace of legal process in these matters be made explicit and intelligible. They desire the advice, the definite guidance, and 
information which can be supplied by and administrative body, and interstate trade commission (in Kolko, 260).

As noted above, J. B. Clark had long been active in the theoretical debates surrounding the "trusts." By the second decade of the 1900's, he became involved at the political level. Indeed, following his 1911 testimony, he co-authored a 1913 Bill sponsored by the National Civic Foundation, the leading big business organization of the day, proposing a seven-person interstate trade commission with fairly broad powers, including the fining of corporations (minimally, to be sure) for violations of existing law. This bill was a precursor of the 1914 Federal Trade Commission Act that was passed in concert with the Clayton Act of that year.

What is thus demonstrated is that Clark was important in the development of anti-trust legislation in the U.S., not just at the theoretical level, but also at the practical, political level. This is in keeping with his ongoing concern with the major issues of his day and his application of the leading theoretical principles to these practically concerns.

*Dipartimento Studi su Politica Diritto e Societ', Universit’ di Palermo, Piazza Bologni, 8, 90134 Palermo, Italy (lucafiorito@sciepol2.unipa.it); Department of Economics, University of Missouri, Kansas City, 5100 Rockhill Road, Kansas City, MO 64110-2499, USA (henryif@umkc.edu). We thank Brenda Dionisi for most helpful editorial assistance.

\section{References}

Bonbright, James, and Means, Gardiner. 1932. The Holding Company: Its public Significance and Its Regulation. New York: McGraw-Hill Book Co.

Clark, John Bates. 1900. “Trusts.” Political Science Quarterly. 15.2 (January). Pp. 181-95. 
1904. “The Real Dangers of the Trusts.” The Century Magazine. 68.6 (October). Pp. 954-9.

Clark, John Maurice. 1958. “Letter to Joseph Dorfman, July 17.” Joseph Dorfman Papers, Rare Book and Manuscript Room, Columbia University.

Dorfman, Joseph. 1971. “John Bates and John Maurice Clark on Monopoly and Competition.” Introduction to John Bates Clark and John Maurice Clark, (1912) 1971, The Control of Trusts. New York: Augustus M. Kelley.

Henry, John F. 1995. John Bates Clark: The Making of a Neoclassical Economist. London: Macmillan Press, Ltd.

Jenks, Jeremiah. 1912. “Economic Aspects of the Recent Decisions of the United States Supreme Court on Trusts.” The Journal of Political Economy. 20.4. Pp. 346-357.

Kolko, Gabriel. 1967. The Triumph of Conservatism. 1967. Chicago: Quadrangle Paperbacks.

Letwin, William. 1965. Law and Economic Policy in America: The Evolution of the Sherman Antitrust Law. New York: Random House.

Liebhafsky, H. H. 1971. American Government and Business. New York: John Wiley and Sons.

Mayhew, Anne. 1998. "How American Economists Came to Love the Sherman Antitrust Act.” History of Political Economy. 30; Supplement. Pp. 179-201.

Martin, David. 1959. Mergers and the Clayton Act. Berkeley and Los Angeles: University of California Press.

Prechel, Harland. 2000. Big Business and the State: Historical Transformations and Corporate Transformations. Albany: State University of New York Press.

Seager, Henry R. 1911. “The Recent Trust Decision.” Political Science Quarterly. 26.4 (December). Pp. 581-614.

Young, Allyn. 1915. “The Sherman Act and the New Anti-Trust Legislation: 1.” The Journal of Political Economy. 23.3. Pp. 201-20. 